\title{
PENGELOLAAN DAYA TARIK WISATA BERBASIS MASYARAKAT DI DESA PECATU, KUTA SELATAN, KABUPATEN BADUNG
}

\author{
I Ketut Yudasuara \\ Email: suarayuda@yahoo.com
}

This study analyzes the tourist attraction management by Pecatu Village, South Kuta, Badung Regency. Through the regulation 20/1994 concerning the Management and Retribution of Tourist Object to manage the Uluwatu Temple outer area as a tourist attraction, Badung Regency Goverment gave license to Pecatu Village to manage those attractions. The purpose of this research is to find out the form, the obstructions and the efforts of Desa Pakraman Pecatu in term of tourism attraction management. Theories utilized in this study included functionalism theory, structuration theory, and the theory of hegemony. The study shows that tourist attraction outside area of Uluwatu Temple is managed directly by Desa Pakraman Pecatu, while other tourist attractions managed by the community in the respected area of the attractions. There are several obstructions that faced by management of tourist attractions, such as limited of human resources, limited of facilities, and limited of fund, lack of management regulation, inter-organizational coordination, and property ownership. The efforts which have been done to solve the problem such as, the establishment of tourist attraction management, the restructurization of tourist attraction, the preparation of the management and retribution regulations, the empowerment of the society, and the improvement of interorganizational cooperation.

Keywords: management, tourist attraction, Uluwatu Temple, community based tourism.

\section{Pendahuluan}

Pariwisata merupakan salah satu sektor yang diandalkan dalam pembangunan di Bali. Berbagai potensi pariwisata yang ada dikembangkan untuk menarik minat wisatawan. Perkembangan pembangunan sarana dan prasarana untuk keperluan pariwisata di Bali Selatan seolah tidak terbendung. Tujuannya jelas untuk menarik wisatawan dan meningkatkan pendapatan dari ekonomi pariwisata.

Kabupaten Badung adalah salah satu kabupaten di Provinsi Bali yang 
pendapatan asli daerahnya 90\% lebih diperoleh dari sektor pariwisata. Daerah tujuan wisata di Kabupaten Badung yang sudah dikenal selama ini, seperti Kuta dan Nusa Dua merupakan daerah wisata yang banyak memberikan kontribusi bagi pendapatan asli daerah Kabupaten Badung (Bappeda Litbang Kabupaten Badung 2011).

Perkembangan kawasan Nusa Dua sebagai destinasi wisata yang terkenal, mendorong desa-desa di sekitarnya seperti Jimbaran, Pecatu, Ungasan, dan Kutuh untuk mengembangkan potensi pariwisata yang dimiliki dalam rangka meningkatkan pendapatan desa serta meningkatkan kesejahteraan masyarakat. Desa Jimbaran memiliki daya tarik wisata pantai dengan kehidupan nelayannya serta lokasinya dekat dengan Bandara Ngurah Rai dan Nusa Dua. Desa Kutuh yang letaknya bersebelahan dengan Nusa Dua juga mengembangkan potensi yang dimiliki sebagai daya tarik wisata yaitu Pantai Pandawa. Desa Ungasan yang lokasinya bersebelahan dengan Desa Kutuh juga sedang mengembangkan potensi wisata yang dimiliki yaitu Pantai Melasti yang terletak di pantai bagian selatan Desa Ungasan.

Desa Pecatu merupakan salah satu desa di kawasan Bukit, Kecamatan Kuta Selatan, Kabupaten Badung juga mengalami perkembangan pariwisata yang pesat. Penduduk Desa Pecatu yang pada awalnya merupakan petani lahan kering dan peternak, saat ini sebagian penduduknya menggantungkan harapan hidupnya dari sektor pariwisata. Topografi wilayah Desa Pecatu berpotensi untuk dikembangkan menjadi daerah tujuan wisata. Potensi alam yang sangat menawan baik tebing, ombak lautan, pantai yang berpasir putih dan daerahnya yang berbukit-bukit.

Kawasan Luar Pura Uluwatu adalah salah satu daya tarik wisata yang ada di Desa Pecatu, dan merupakan sumber pendapatan masyarakat dan penyumbang terbesar bagi pendapatan asli desa. Pura yang berada di atas tebing terjal dengan ketinggian 165 meter di atas permukaan laut dan menghadap ke Samudra Indonesia, serta peristiwa alam berupa matahari terbenam merupakan daya tarik bagi wisatawan untuk berkunjung ke tempat ini.

Dalam upaya untuk memperoleh manfaat yang sebesar-besarnya bagi kesejahteraan masyarakat dan peningkatan pendapatan asli desa, diperlukan upaya-upaya dalam pengembangan dan pengelolaan sumber daya pariwisata yang ada di Desa Pecatu. Peran dari Desa Pakraman Pecatu sangat penting, karena kepemilikan dari sumber daya pariwisata sebagian besar merupakan aset dari Desa Pakraman Pecatu. Berdasarkan Peraturan Daerah Kabupaten Badung Nomor 20 tahun 1994 tentang Pengusahaan dan Retribusi Objek Wisata, yang kemudian diperkuat dengan Surat Keputusan Bupati Badung Nomor 854 Tahun 1996 tentang Penunjukan Pengusahaan Objek dan Daya Tarik Wisata Kawasan Luar Pura Uluwatu, maka Desa Pakraman Pecatu diizinkan untuk terlibat secara langsung dalam pengelolaan daya tarik wisata 
khususnya Kawasan Luar Pura Uluwatu.

Sesuai dengan misi pembangunan dan rencana tata ruang Kabupaten Badung yang menyatakan bahwa lembaga-lembaga kemasyarakatan yang telah ada dan relevan dalam menunjang keajegan Bali dan kesejahteraan penduduk lokal perlu lebih diberdayakan (Profil Wilayah Kabupaten Badung Tahun 2010). Desa Pakraman sejak zaman dahulu telah berperan dalam meningkatkan kesejahteraan masyarakat dan menjaga adat dan budaya Bali. Desa Pakraman Pecatu dan Pemerintah Daerah Kabupaten Badung merupakan pihak yang memiliki serta mengelola daya tarik wisata Kawasan Luar Pura Uluwatu. Desa Pakraman Pecatu dihadapkan pada suatu peluang dan tantangan dalam pengelolaan sumber daya pariwisata yang ada di Desa Pecatu.

Berdasarkan latar belakang tersebut, maka masalah penelitian ini dirumuskan sebagai berikut (1) bagaimanakah bentuk pengelolaan daya tarik wisata oleh Desa Pakraman Pecatu?; (2) apakah kendala-kendala yang dihadapi?; dan (3) bagaimanakah upaya-upaya Desa Pakraman dalam pengelolaan daya tarik wisata di Desa Pecatu, Kecamatan Kuta Selatan, Kabupaten Badung?

\section{Teori dan Metode}

Teori yang digunakan dalam penelitian ini adalah teori fungsionalisme struktural, teori strukturasi, dan teori hegemoni. Menurut Robert King Merton teori fungsionalisme memandang segala pranata sosial yang ada dalam suatu masyarakat tertentu serba fungsional baik positif maupun negatif. Masyarakat senantiasa berada dalam keadaan berubah secara pelan dan tetap memelihara keseimbangan (Ritzer dan Goodman 2003). Analisis struktural fungsional memusatkan perhatian pada kelompok, organisasi, masyarakat dan kultur. Setiap objek yang dapat dijadikan sasaran analisis struktural fungsional tentu mencerminkan hal yang standar, yaitu terpola dan berulang. Merton juga mengemukakan konsep fungsi nyata (manifest) dan fungsi tersembunyi (latent). Fungsi nyata adalah fungsi yang diharapkan, sedangkan fungsi yang tersembunyi adalah fungsi yang tidak diharapkan (Ritzer dan Goodman 2003), maka dalam struktur yang ada, hal-hal yang tidak relevan dipengaruhi secara fungsional dan disfungsional.

Teori struturasi diperkenalkan oleh Anthony Giddens tahun 1975. Setiap riset pada ilmu sosial atau sejarah selalu menyangkut hubungan tindakan yang sering kali disinonimkan dengan agen dan struktur sebaliknya (Ritzer dan Goodman 2003). Bidang mendasar studi ilmu sosial menurut teori strukturasi adalah praktik sosial yang diatur melintasi ruang dan waktu. Tindakan yang berulang-ulang dari agenlah yang mereproduksi struktur tersebut. Seluruh tindakan sosial memerlukan struktur dan seluruh struktur memerlukan tindakan sosial. Strukturasi meliputi hubungan dialektika 
antara agen dan struktur. Struktur dan keagenan adalah dualitas, struktur tidak akan ada tanpa keagenan demikian pula sebaliknya.

Teori hegemoni diperkenalkan oleh Antonio Gramsci. Hegemoni adalah situasi dimana suatu blok historis faksi kelas berkuasa menjalankan otoritas sosial dan kepemimpinan atas kelas-kelas subordinat melalui kombinasi antara kekuatan dan terlebih lagi dengan konsensus (Barker 2004). Hegemoni merupakan sebuah proses penguasaan kelas dominan kepada kelas bawah, dan kelas bawah juga aktif mendukung ide-ide kelas dominan. Penguasaan tersebut dilakukan melalui persetujuan masyarakat.

Teknik pengumpulan data dengan observasi, wawancara, dan studi dokumentasi. informan terdiri dari prajuru Desa Pakraman, Pemerintah Desa Pecatu, Dinas Pariwisata Kabupaten Badung, pengelola daya tarik wisata, kelompok sadar wisata, pedagang dan masyarakat yang ada di sekitar daya tarik wisata. Analisis data menggunakan analisis deskriptif kualitatif.

\section{Bentuk Pengelolaan Daya Tarik Wisata oleh Desa Pakraman Pecatu}

Wilayah Desa Pakraman Pecatu sebagian besar dikelilingi oleh pantai yang merupakan daya tarik bagi wisatawan. Pantai-pantai tersebut sudah berkembang walaupun belum dikelola dengan baik. Menurut Peraturan Bupati Badung Nomor o7 Tahun 2005 tentang Objek dan Daya Tarik Wisata di Kabupaten Badung, dari 33 daya tarik wisata di Kabupaten Badung, lima di antaranya berlokasi di Desa Pecatu, yaitu Kawasan Luar Pura Uluwatu, Pantai Suluban, Pantai Padang Padang, Pantai Labuhan Sait, dan Pantai Nyang Nyang. Selain itu, ada dua pantai yang dapat dikembangkan sebagai diversifikasi produk wisata, seperti Pantai Bingin dan Pantai Dream Land. Pengelolaan dengan manajemen yang lebih baik menjadi sebuah keharusan agar memberikan nilai atau manfaat bagi Desa Pakraman.

Berdasarkan awig-awig Desa Pakraman Pecatu, bahwa kekeran tanah ngampan, yaitu hutan dari tanah miring atau sempadan pantai yang ada di wilayah Desa Pakraman Pecatu merupakan milik dari Desa Pakraman Pecatu. Hal ini memiliki arti yang positif untuk mempertahankan pantai agar tidak beralih fungsi dan kepemilikan, serta menjaga akses masyarakat agar tetap dapat menggunakan pantai untuk berbagai kegiatan adat, agama dan kepentingan masyarakat umum. Desa Pakraman Pecatu memiliki tanggung jawab, hak dan kewajiban untuk memelihara, mempertahankan dan mengelola pantai yang ada dalam upaya untuk menjaga kelestarian alam, adat, budaya dan agama serta meningkatkan kesejahteraan masyarakatnya.

\subsection{Pengelolaan daya tarik wisata Kawasan Luar Pura Uluwatu}

Tanggung jawab pengelolaan mencakup pemeliharaan, pelestarian, penataan, keamanan dan hak melakukan pungutan retribusi masuk bagi wisatawan yang berkunjung. Walaupun kepercayaan dalam pengelolaan daya 


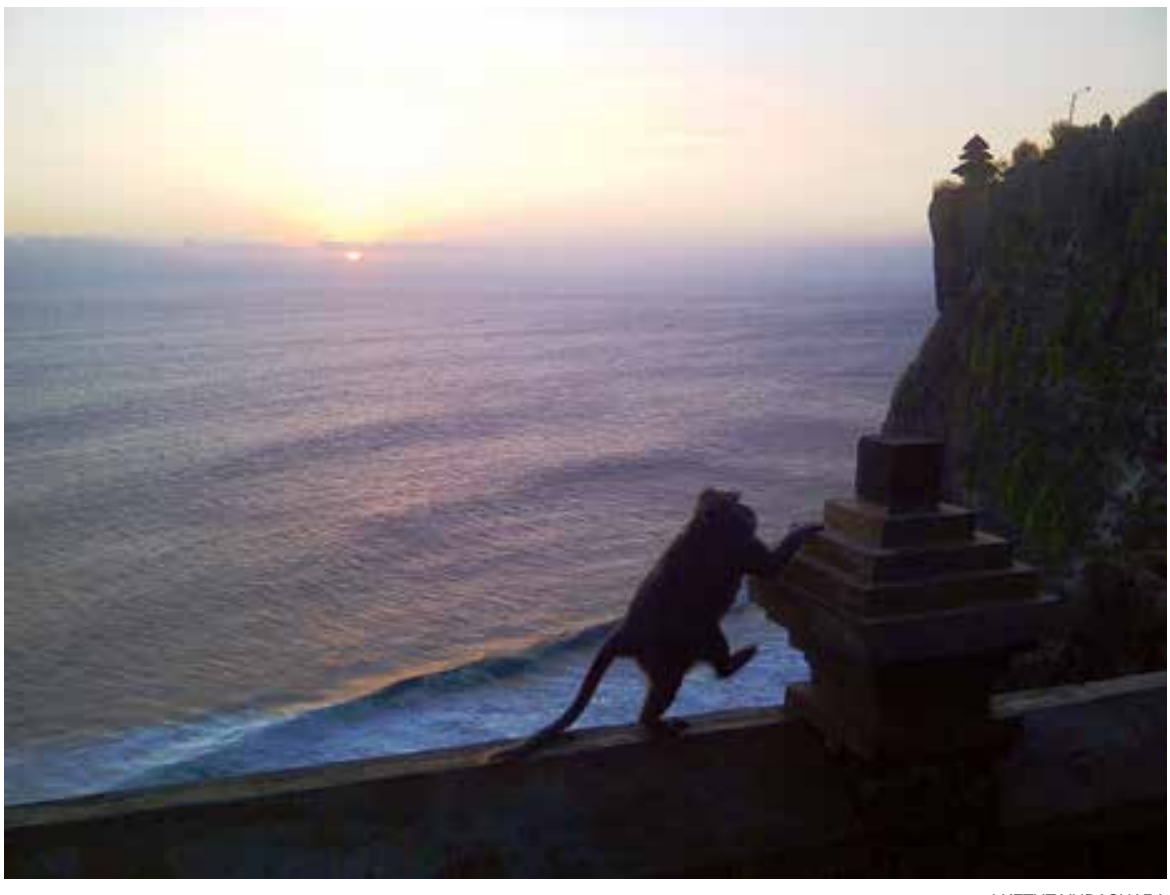

Foto 1. Sunset di Uluwatu dan seekor kera di tembok pura.

tarik wisata Kawasan Luar Pura Uluwatu diberikan kepada Desa Pakraman Pecatu, sebenarnya ada beberapa pihak yang juga bertanggung jawab dan berperan dalam pengelolaan, yaitu Pemerintah Kabupaten Badung sebagai penanggung jawab kewilayahan, fasilitator, pembina dan pengawas pengelolaan, Pemerintah Desa Pecatu, pihak keluarga Puri Jro Kuta dan keluarga Puri Celagi Gendong Denpasar sebagai pengempon yang berperan pada pelaksanaan upacara keagamaan.

Daya tarik wisata Kawasan Luar Pura Uluwatu selama ini sudah dikelola dengan baik oleh Desa Pakraman Pecatu(Foto 1). Pengelolaannya bekerja sama dengan Pemerintah Desa Pecatu dan memberdayakan masyarakat setempat. Secara struktur pengelola, diketuai oleh Kepala (Kelihan) Desa Adat Pecatu, dibantu oleh pengurus adat yang lain. Pengelola memberdayakan warga Desa Pakraman Pecatu untuk dipekerjakan sebagai petugas pengelolaan. Para petugas pengelola juga dibantu oleh para pedagang di kios-kios dan dua grup kecak yang tergabung dalam kelompok Sadar Wisata Kawasan Luar Pura Uluwatu. Pengelolaan juga melibatkan para pecalang (petugas keamanan) dari Desa Pakraman Pecatu dan petugas Hansip dari Pemerintah Desa Pecatu.

Pengelolaan daya tarik wisata Kawasan Luar Pura Uluwatu melibatkan berbagai unsur masyarakat setempat, mulai dari proses perencanaan, pelaksanaan dan pengawasan. Pihak pemerintah Kabupaten Badung 
berupaya melakukan pengembangan fisik dan non-fisik. Setiap perencanaan dan pengembangan pembangunan harus dimasukkan dalam program kerja prajuru Desa Pakraman dan Pemerintah Desa Pecatu.

Tahap pengorganisasian dan pelaksanaan dengan memberdayaan masyarakat asli warga Desa Pakraman Pecatu. Petugas pengelola mendapatkan berbagai pembinaan dan pelatihan, seperti kursus bahasa asing, pemandu wisata, adat dan budaya serta sistem pengelolaan daya tarik wisata.

Menurut Kelihan Desa Adat Pecatu, kekuatan dalam pengelolaan daya tarik wisata Kawasan Luar Pura Uluwatu adalah adanya semangat dan tekad bersama di tingkat kelembagaan di desa, daya tarik yang dimilikinya, dan tenaga pengelola yang sudah berpengalaman. Mekanisme penempatan personil didasarkan atas kompetensi yang dimiliki oleh personil tersebut sesuai dengan pos yang ada.

Salah satu indikator keberhasilan pengelola dalam melaksanakan tugasnya adalah pada peningkatan jumlah kunjungan wisatawan dan pendapatan dari retribusi masuk seperti pada Tabel 1 .

Tabel 1 Jumlah Kunjungan Wisatawan dan Hasil Retribusi Pengelolaan Kawasan Luar Pura Uluwatu Tahun 2006 -2011

\begin{tabular}{cccc}
\hline No. & Tahun & $\begin{array}{c}\text { Kunjungan Wisatawan } \\
\text { (orang) }\end{array}$ & Hasil Retribusi (rupiah) \\
\hline 1 & 2006 & 290.790 & 629.370 .000 \\
2 & 2007 & 315.652 & 946.956 .000 \\
3 & 2008 & 380.116 & 1.140 .348 .000 \\
4 & 2009 & 380.224 & 1.142 .455 .500 \\
5 & 2010 & 402.351 & 1.208 .940 .000 \\
6 & 2011 & 378.175 & 1.134 .525 .000 \\
\hline
\end{tabular}

Sumber: Pengelola Daya Tarik Wisata Kawasan Luar Pura Uluwatu, tahun 2014

Sejak berlakunya Perda Kabupaten Badung Nomor 25 Tahun 2011 tentang Retribusi Tempat Rekreasi dan Olah Raga di mana besarnya tarif retribusi meningkat dari Rp. 3.000 menjadi Rp. 15.000 untuk dewasa domestik, dari Rp. 5.000 menjadi Rp. 20.000 untuk dewasa asing. Hal ini menuntut pengelola untuk melakukan upaya-upaya antara lain membenahi sistem penjualan tiket, meningkatkan kebersihan, menertibkan kera-kera yang agak nakal, memberdayakan petugas keamanan, mengadakan pelatihan dan meningkatkan promosi.

Pembenahan yang dilakukan pengelola telah berhasil menunjukkan kinerjanya dengan meningkatnya jumlah kunjungan wisatawan dan hasil retribusi masuk secara signifikan. Jumlah kunjungan wisatawan tahun 2012 sebesar 843.876 orang meningkat 123,14 \% dari tahun 2011. Pada tahun 2013 sebesar 884.086 orang meningkat 4,76 \% dan tahun 2014 sebesar 795.911 orang menurun 9,97\%. Pandapatan retribusi masuk pada tahun 2012 sebesar 


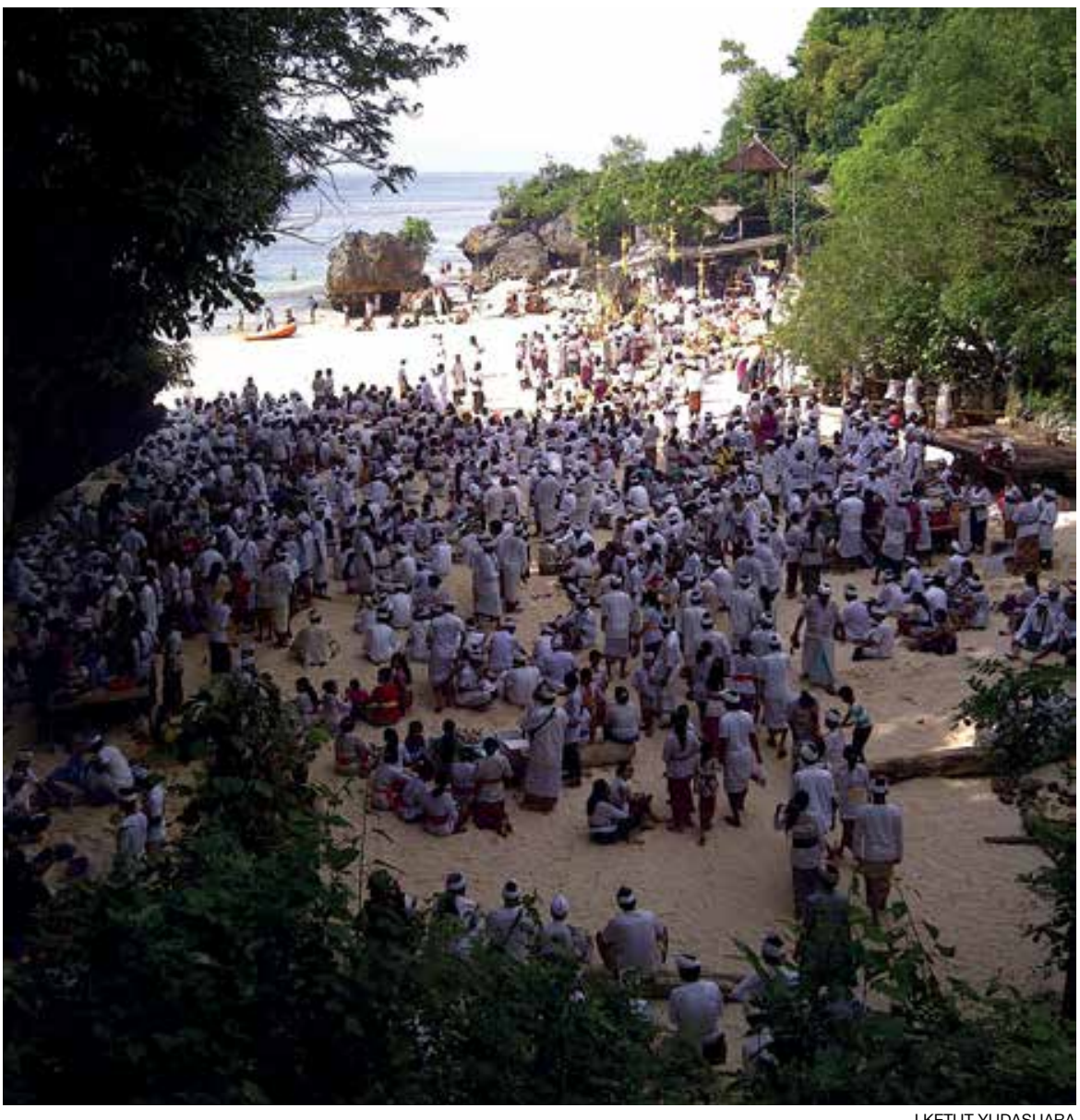

Foto 2. Pemandangan Pantai Suluban.

Rp. 14.874.930.000 meningkat 1.211,11 \% dari tahun 2011. Pada tahun 2013 sebesar Rp. 15.278.315.000 meningkat sebesar 2,71 \% dan tahun 2014 sebesar Rp. 12.649.317.000 menurun 17,21 \%.

Pengawasan terhadap pengelolaan dilakukan oleh Pemerintah Kabupaten Badung melalui Dinas Pariwisata dengan monitoring dan evaluasi setiap akhir bulan. Pengawasan juga dilakukan melalui mekanisme lembagalembaga yang ada di desa, seperti Desa Pakraman dan Pemerintah Desa.

Hasil dari pengelolaan daya tarik wisata Kawasan Luar Pura Uluwatu telah dapat dirasakan manfaatnya oleh warga masyarakat yang bekerja di kawasan ini. Secara tidak langsung digunakan oleh prajuru Desa Pakraman Pecatu untuk membiayai berbagai program pembangunan serta membiayai berbagai kegiatan upacara keagamaan, sehingga warga masyarakat tidak terbebani dengan biaya-biaya untuk pembangunan dan upacara keagamaan di lingkungan Desa Pakraman Pecatu. 
Pola pembagian bulanan dari hasil retribusi masuk adalah 25\% disetorkan kepada Pemerintah Kabupaten Badung dan $75 \%$ untuk Desa Pakraman Pecatu sebagai pengelola. Pembagian untuk Desa Pakraman diatur kesepakatannya dengan pihak Pemerintah Desa. Pendapatan lainnya adalah dari penyewaan kios, retribusi parkir dan pungutan pementasan tari kecak.

\subsection{Pengelolaan Daya Tarik Wisata Pantai Suluban}

Pantai Suluban terletak 1,5 km dari Pura Uluwatu. Pantai ini memiliki ombak laut yang tinggi dan pemandangan matahari terbenam dari ketinggian tebing (Foto 2). Pada awalnya, akses menuju ke Pantai Suluban adalah jalan setapak melalui lahan-lahan milik penduduk. Berdasarkan kesepakatan, para warga di sekitar yang merelakan lahannya dijadikan jalan menuju ke Pantai Suluban dari arah Pura Uluwatu. Pantai Suluban sampai saat ini dikelola oleh para pemilik lahan yang dijadikan jalan dalam satu wadah yang disebut sekaha jalan. Pemasukan yang diperoleh dari kelompok ini adalah dari retribusi parkir wisatawan yang berkunjung ke Pantai Suluban. Kawasan ini telah mampu memberikan manfaat ekonomi khususnya bagi warga masyarakat di sekitarnya, walaupun belum terbentuk badan pengelola oleh Desa Pakraman.

\subsection{Pengelolaan Daya Tarik Wisata Pantai Padang Padang}

Pantai Padang Padang berlokasi di sebelah utara dari Pantai Suluban. Pantai ini dikenal oleh wisatawan, karena sering diselenggarakan kegiatan berselancar tingkat dunia. Kunjungan wisatawan ke pantai ini dimanfaatkan oleh pemilik-pemilik lahan yang berada di sekitar pantai untuk membangun beberapa usaha pariwisata. Belum terbentuk manajemen pengelolaan oleh Desa Pakraman Pecatu. Walaupun demikian, perkembangan Pantai Padang Padang telah mampu memberikan manfaat ekonomi bagi warga sekitarnya.

\subsection{Pengelolaan daya tarik wisata Pantai Labuhan Sait}

Daya tarik wisata Pantai Labuhan Sait lokasinya bersebelahan dengan Pantai Padang Padang. Pantai Labuhan Sait merupakan tempat yang digunakan untuk upacara keagamaan yaitu melasti (Foto 3). Pantai ini mampu memberikan kontribusi bagi pendapatan Pemerintah Desa Pecatu, yaitu dari hasil menyewakan kios, retribusi parkir dan bagi hasil penggunaan toilet. Hasil dari pendapatan desa ini digunakan untuk membiayai programprogam pembangunan. Pantai Labuhan Sait telah mampu meningkatkan taraf ekonomi warga masyarakat. Pantai Labuhan Sait dikelola oleh kelompok masyarakat di sekitarnya yang mencari kehidupan di pantai ini, seperti kelompok pedagang, nelayan, petugas parkir dan penyedia jasa wisata yang tergabung dalam kelompok sadar wisata. Belum terbentuk badan pengelola oleh Desa Pakraman. 


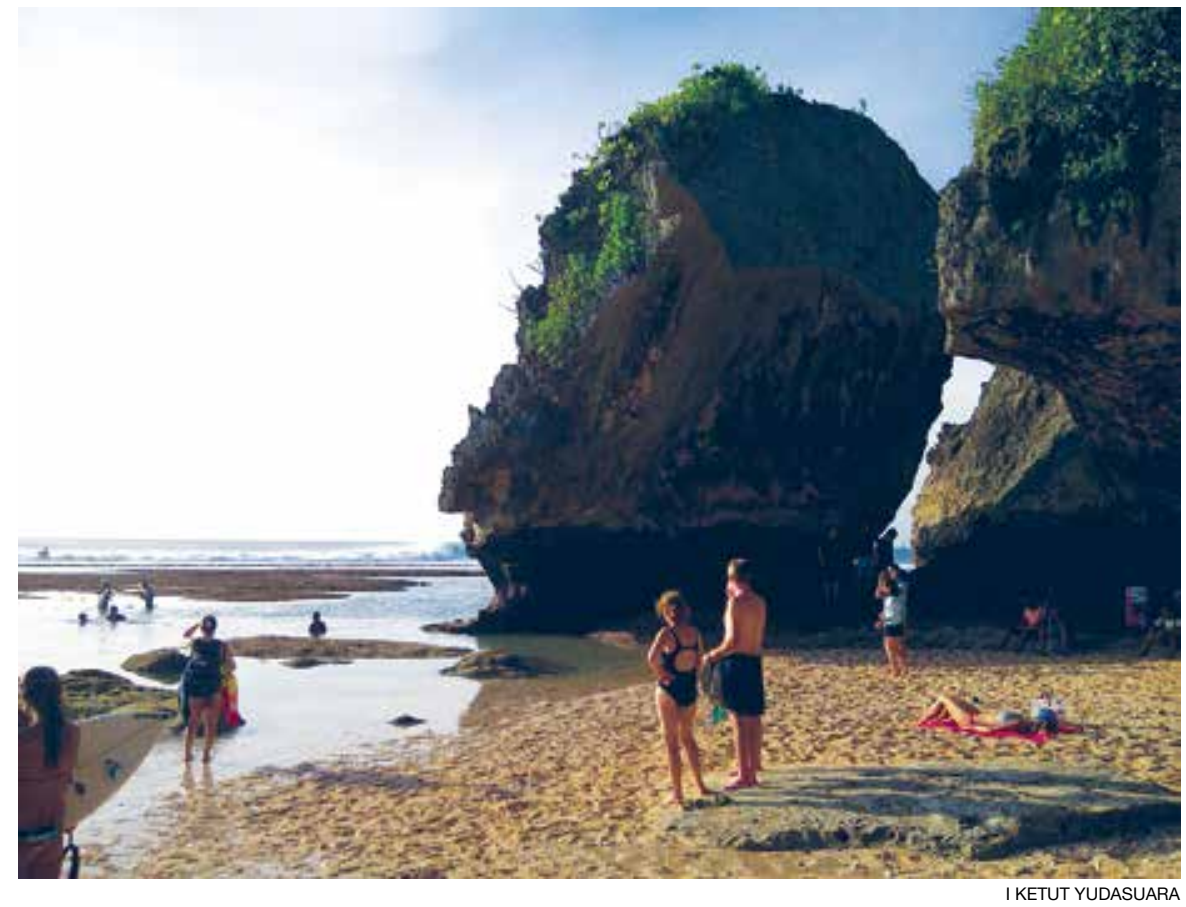

Foto 3. Suasana melasti di Pantai Labuhan Sait.

\subsection{Pengelolaan daya tarik wisata Pantai Bingin}

Perkembangan Pantai Bingin sampai dikenal oleh wisatawan adalah berkat rintisan dari masyarakat yang ada di sekitarnya yang berjumlah 25 orang. Dengan memanfaatkan sempadan pantai yang merupakan tanah negara, mereka membangun berbagai usaha jasa wisata. Belum terbentuk badan pengelola oleh pihak Desa Pakraman. Pantai Bingin dikelola oleh warga masyarakat sekitar terutama yang merintis pengembangan awal.

\subsection{Pengelolaan daya tarik wisata Pantai Nyang Nyang}

Daya tarik dari Pantai Nyang Nyang adalah pemandangan laut yang luas dan tebing dengan ketinggian sekitar 500 meter. Pantai Nyang Nyang selama ini dikelola oleh pihak swasta yaitu PT Puri Bali. Pihak swasta ini mengelola vila dan restoran yang berada di atas tebing dari Pantai Nyang Nyang. Wisatawan yang datang umumnya mereka yang membeli paket wisata dan singgah untuk coffee break sambil menikmati keindahan pantai dari ketinggian.

Pihak Desa Pakraman Pecatu sampai saat ini belum ada upaya untuk pengembangan dan pengelolaan Pantai Nyang Nyang. Manfaat ekonomi yang langsung dirasakan bagi warga Desa Pecatu adalah sebagai staf dan manajemen dari Puri Bali Villas and Restaurant 


\subsection{Pengelolaan daya tarik wisata Pantai Dream Land}

Pantai Dream Land mulai dikenal oleh wisatawan setelah dibukanya kawasan wisata Bali Pecatu Graha. Fasilitas jalan menuju ke pantai dan fasilitas parkir adalah milik dari PT. Bali Pecatu Graha sebagai pengelola kawasan. Sampai saat ini, belum terbentuk badan pengelola oleh Desa Pakraman Pecatu. Pengelolaan baru pada tahap penyewaan 30 unit kios milik Desa Pakraman Pecatu yang disewakan kepada kelompok pedagang warga sekitarnya. Selama ini Pantai Dream Land dikelola oleh kelompok pedagang penyewa kios, penyewaan payung pantai, penyedia jasa panti pijat, penyewaan papan selancar dan petugas penyelamat pantai.

Mengacu pada teori fungsionalisme struktural bahwa pengelolaan Kawasan Luar Pura Uluwatu adalah merupakan fungsi nyata (manifest) dari peran Desa Pakraman Pecatu. Sedangkan daya tarik wisata yang lain, Desa Pakraman belum melaksanakan fungsinya karena berbagai pertimbangan dan kendala yang dihadapi. Fungsi tersebut merupakan konsekuensi objektif yang dapat memberikan sumbangan pada adaptasi sistem yang dikehendaki dan disadari oleh sistem tersebut, yakni masyarakat dengan berbagai unsurnya.

Bentuk pengelolaan merupakan program yang telah direncanakan. Daya tarik wisata lainnya, selama ini belum dibentuk pengelolaan oleh Desa Pakraman Pecatu, sehingga belum memberikan kontribusi bagi pendapatan desa. Mengacu pada teori strukturasi bahwa program yang dijalankan oleh Desa Pakraman merupakan sebuah praktek sosial yang berulang-ulang yang menghubungkan antara agen (prajuru) dan struktur (warga masyarakatnya). Prajuru dan warga masyarakat saling mempengaruhi (dualitas) sehingga praktek sosial yang berulang-ulang berupa program pengelolaan daya tarik wisata dapat terselenggara.

Mengacu pada teori hegemoni bahwa keberadaan prajuru Desa Pakraman Pecatu dalam praktek sosial di masyarakat merupakan kelompok dominan. Prajuru menjalankan fungsinya menggunakan seperangkat ideologi, ke dalam program-program yang sistematis untuk membangkitkan kesadaran warga masyarakat. Ideologi menyuguhi orang dengan aturan bagi tindakan praktis dan perilaku moral. Ideologi adalah pengalaman yang hidup sekaligus sebagai perangkat ide sistematis yang peranannya adalah mengorganisasi dan mengikat secara bersama-sama dalam satu blok berbagai elemen sosial dalam pembentukan blok hegemoni dan kontra hegemoni (Barker, 2004).

\section{Kendala Dalam Pengelolaan Daya Tarik Wisata di Desa Pecatu}

Beberapa program yang telah dibuat oleh Desa Pakraman Pecatu dalam pengelolaan daya tarik wisata belum dapat terlaksana karena beberapa kendala sebagai berikut. 


\subsection{Keterbatasan sumber daya manusia}

Pengelolaan daya tarik wisata yang lebih profesional, membutuhkan kemampuan manajerial dari pengelolanya. Hal ini merupakan kendala utama. Hampir sebagian besar daya tarik wisata yang dimiliki belum didukung oleh sumber daya manusia yang memadai baik dari kualitas maupun kuantitas.

Keterbatasan sumber daya manusia salah satunya disebabkan oleh kondisi demografis, seperti tingkat pendidikan dan minimnya pengalaman dalam bidang manajemen. Pengelolaan daya tarik wisata yang ada di Desa Pakraman Pecatu diprioritaskan kepada warga asli dari Desa Pakraman Pecatu. Dari beberapa daya tarik wisata, baru Kawasan Luar Pura Uluwatu yang sudah memiliki tenaga pengelola berpengalaman.

\subsection{Keterbatasan fasilitas wisata}

Sebagian besar daya tarik wisata yang ada di Desa Pecatu belum memiliki sarana dan prasarana yang memadai. Dari tujuh daya tarik wisata yang ada di Desa Pakraman Pecatu hanya daya tarik wisata Kawasan Luar Pura Uluwatu yang sudah memiliki fasilitas dan infrastruktur yang memadai.

Belum tersedianya sarana prasarana yang layak untuk wisatawan, membuat pihak Desa Pakraman belum berani untuk melakukan pungutan retribusi masuk. Pantai yang lain belum dilengkapi dengan infrastruktur jalan yang representatif khusus untuk akses jalan masuk dari jalan utama menuju area pantai. Selama ini, wisatawan yang ingin menuju ke pantai harus melewati jalan setapak yang kondisinya belum bagus.

\subsection{Keterbatasan dana}

Masalah keterbatasan dana, terutama untuk menyiapkan fasilitas fisik dan sumber daya manusia yang profesional. Pembangunan sarana dan prasarana wisata pada daya tarik wisata di Desa Pecatu merupakan tanggung jawab dari Desa Pakraman Pecatu. Walaupun daya tarik wisata tersebut merupakan aset dari Desa Pakraman Pecatu, pembangunannya juga merupakan tanggung jawab dari pihak pemerintahan. Pengalokasian anggaran untuk program pembangunan fisik harus mendapatkan persetujuan dari warga masyarakat Desa Pakraman dan tidak membebani anggaran untuk kebutuhan biaya rutin, seperti biaya berbagai upacara agama dan adat.

\subsection{Sosial kemasyarakatan}

Faktor sosial kemasyarakatan merupakan kendala yang memerlukan proses untuk mengatasinya. Ada beberapa faktor yang melatarbelakanginya, seperti faktor kepentingan, ekonomi, pendidikan dan budaya. Beberapa kasus yang muncul antara lain penolakan warga atas program penataan pantai dari usaha wisata yang berada di sempadan pantai dan pedagang di pantai, munculnya penguasa-penguasa wilayah yang baru dan pementasan tari kecak 


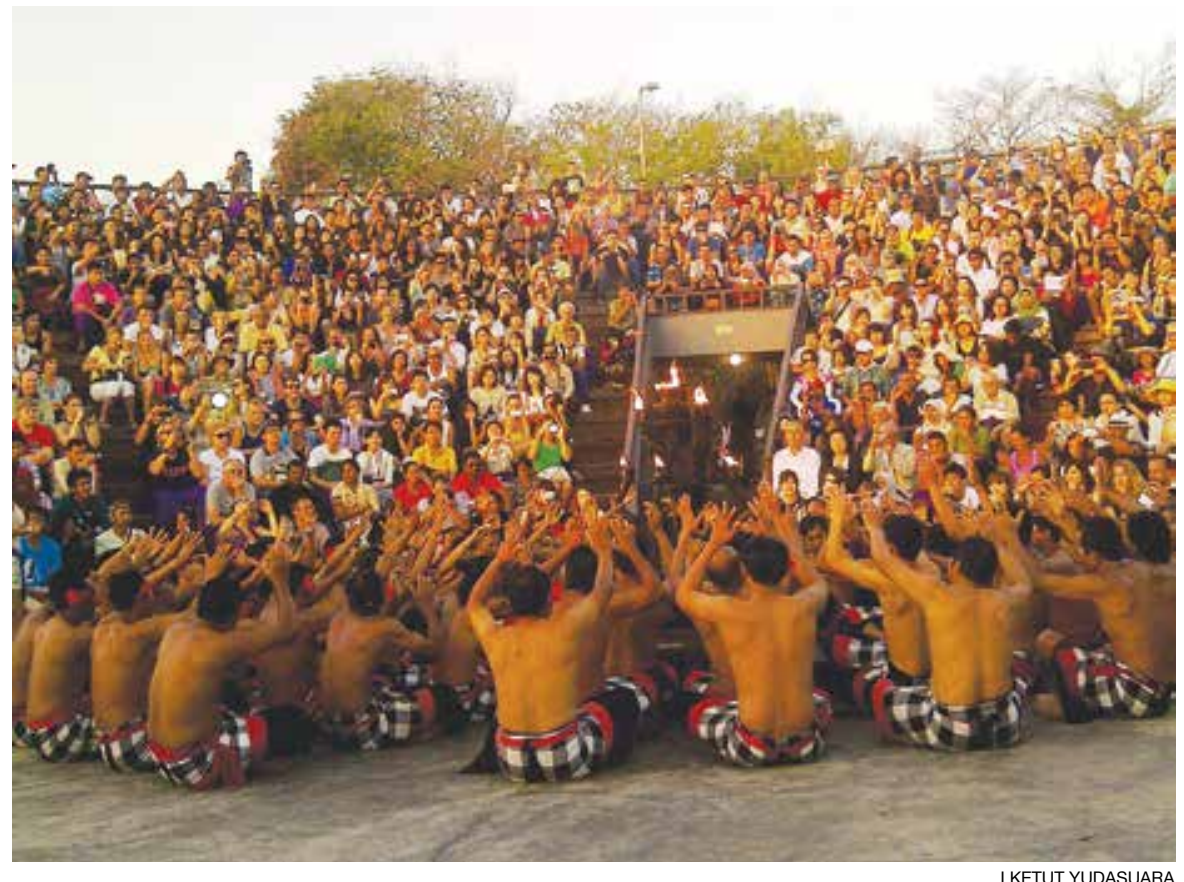

Foto 4. Pentas kecak setiap sore di samping Pura Uluwatu.

di sisi luar bagian selatan Pura Uluwatu yang tidak adil bagi sebagian warga Desa Pakraman Pecatu (Foto 4). Kendala sosial kemasyarakatan ini tidak dapat dihindari karena ada konflik kepentingan dalam pengelolaan daya tarik wisata.

\subsection{Regulasi pengelolaan}

Dari tujuh daya tarik wisata yang ada di Desa Pakraman Pecatu, hanya daya tarik wisata Kawasan Luar Pura Uluwatu yang sudah memiliki dasar hukum pengelolaan. Belum adanya regulasi membuat Desa Pakraman Pecatu, belum berani melakukan langkah-langkah pengelolaan termasuk melakukan pungutan, baik retribusi masuk bagi wisatawan maupun parkir kendaraan. Pantai yang merupakan fasilitas umum di mana setiap orang bebas masuk tanpa dikenai pungutan, sehingga untuk melakukan pungutan harus ada aturan yang jelas yang tidak bertentangan dengan peraturan perundang-undangan yang berlaku.

\subsection{Koordinasi antar lembaga dan unsur masyarakat}

Antara Desa Pakraman dan Pemerintah Desa terkadang saling mengakui bahwa dalam bidang tertentu bukan menjadi tanggung jawabnya, demikian juga sebaliknya. Secara kewilayahan antara Desa Pakraman Pecatu dengan Pemerintah Desa Pecatu memiliki wilayah yang sama. Hasil pengamatan 
di area parkir Kawasan Luar Pura Uluwatu dimana kendaraan para wisatawan tidak ada petugas dari pengelola kawasan yang mengatur. Hal ini dikarenakan pungutan retribusi parkir merupakan pendapatan Pemerintah Desa, sedangkan petugas yang ada di kawasan merupakan petugas pengelola yang dibayar oleh Desa Pakraman Pecatu.

\subsection{Kepemilikan Iahan}

Lahan-lahan yang ada di sekitar daya tarik wisata termasuk akses jalan dimiliki oleh perseorangan baik warga Desa Pakraman Pecatu maupun orang luar yang umumnya adalah investor. Lahan yang dimiliki oleh Desa Pakraman Pecatu adalah lahan pada daya tarik wisata Kawasan Luar Pura Uluwatu dan Pantai Labuhan Sait. Pada Pantai Dream Land, akses jalan dan lahan di sekitarnya dimiliki oleh pihak PT Bali Pecatu Graha. Lahan di sekitar daya tarik wisata tersebut sudah difungsikan untuk membangun berbagai sarana dan usaha pariwisata. Mengakomodasikan berbagai kepentingan dari para pemilik lahan sehingga daya tarik wisata tersebut dapat dikelola dengan baik.

Mengacu pada teori fungsionalisme struktural bahwa fungsi yang tidak diharapkan (latent) terjadi pada kendala keterbatasan sumber daya manusia, keterbatasan sarana prasarana wisata dan keterbatasan dana. Fungsi latent adalah konsekuensi obyektif dari suatu kondisi yang tidak dikehendaki maupun disadari oleh masyarakat.

Kendala-kendala yang dihadapi oleh Desa Pakraman Pecatu menurut teori hegemoni merupakan kendala pelaksanaan peran yang berakibat gagalnya penguasaan kelas dominan yakni prajuru terhadap warga masyarakat Desa Pakraman Pecatu. Hal tersebut dapat terjadi karena adanya pemaksaan ideologi yang dilakukan oleh prajuru terhadap warga masyarakatnya. Kendala sosial kemasyarakatan dan kepemilikan lahan merupakan fakta sosial di mana prajuru Desa Pakraman Pecatu belum menguasai kelas bawah.

\section{Upaya-Upaya dalam Pengelolaan Daya Tarik Wisata di Desa Pecatu}

Dengan mengidentifikasikan berbagai potensi wisata yang ada dan kendala-kendala yang dihadapi saat ini Desa Pakraman Pecatu sudah, sedang dan akan dilakukan beberapa upaya sebagai berikut.

\subsection{Pembentukan manajemen daya tarik wisata}

Pada tahap awal, daya tarik wisata Kawasan Luar Pura Uluwatu dijadikan sebagai skala prioritas. Pembentukan manajemen daya tarik wisata Kawasan Luar Pura Uluwatu diawali dengan pembentukan Tim Pengkajian pada akhir tahun 2011. Tim Pengkajian terdiri atas unsur Desa Pakraman, pemerintah desa, tokoh masyarakat, profesional dan akademisi. Berdasarkan hasil kajian tersebut, Desa Pakraman Pecatu sudah membentuk manajemen pengelolaan 
daya tarik wisata Kawasan Luar Pura Uluwatu. Manajemen mulai bertugas bulan juni 2014. Pembentukan manajemen daya tarik wisata dilakukan secara bertahap sambil menyiapkan sarana dan fasilitas pendukung serta menyiapkan regulasi yang akan menjadi dasar hukum pengelolaan.

\subsection{Penataan daya tarik wisata}

Sebagian besar daya tarik wisata yang ada belum dilengkapi dengan fasilitas yang memadai. Daya tarik wisata Kawasan Luar Pura Uluwatu sudah melakukan pembenahan dengan membangun dan menata fasilitas-fasilitas seperti tempat parkir, menambah fasilitas toilet, melengkapi petunjuk atau papan informasi.

Program penataan terhadap daya tarik wisata Pantai Labuhan Sait adalah perluasan parkir, pembangunan tempat penambatan perahu, kios pedagang, membangun toilet, terowongan, membangun candi bentar dan penyediaan fasilitas air dan listrik. Membangun jalan setapak di Pantai Suluban dan melengkapi masing-masing daya tarik wisata dengan papan informasi.

\subsection{Menyiapkan regulasi tentang pengelolaan daya tarik wisata dan retribusi}

Sebagai prioritas pengembangan dan pengelolaan untuk tahap kedua adalah Pantai Labuhan Sait. Desa Pakraman Pecatu segera akan berkonsultasi dan mengajukan usulan kepada Pemerintah Kabupaten Badung tentang dasar hukum yang dapat digunakan dalam pengelolaan dan pungutan retribusi daya tarik wisata Pantai Labuhan Sait, sehingga pungutan yang dilakukan tidak bertentangan dengan peraturan perundang-undangan yang berlaku.

\subsection{Pemberdayaan masyarakat Desa Pakraman Pecatu}

Pemberdayaan dalam jangka pendek lebih ditekankan pada aspek peningkatan ketrampilan, sesuai dengan potensi ekonomi dari pariwisata yang secara langsung dapat dirasakan oleh masyarakat, dan untuk jangka panjang bertujuan menyiapkan sumber daya manusia yang memiliki kompetensi agar nantinya dapat berperan dalam pembangunan kepariwisataan.

Pemberdayaan masyarakat pada bidang ekonomi diarahkan pada peningkatan kesejahteraan masyarakat, yang meliputi pelatihan kewirausahaan, pelatihan usaha produktif dan pelatihan ketrampilan bagi rumah tangga sasaran. Bidang sosial budaya meliputi pelaksanaan ngaben dan nyekah masal dan pengalokasikan dana sosial LPD untuk program pelatihan seni, adat dan upakara. Bidang pendidikan dan pelatihan meliputi pelatihan kecakapan hidup, pembinaan kelompok sadar wisata, pemandu wisata lokal, pecalang, pengelolaan sampah, kesehatan masyarakat, ketrampilan di bidang perhotelan, kegiatan pasraman dan pemberian beasiswa. 


\subsection{Meningkatkan kerja sama antar lembaga}

Keterpaduan antar lembaga selama ini masih belum optimal. Masingmasing lembaga membuat program sendiri-sendiri atau saling menunggu satu sama lain. Upaya yang segera akan dilakukan adalah duduk bersama dan mencari solusi agar lembaga-lembaga yang ada dapat bersinergi terutama dalam merancang pembangunan di Desa Pecatu. Beberapa pengusaha di bidang pariwisata dan lembaga sosial turut peduli pada pengembangan pariwisata di Desa Pecatu antara lain dengan memberikan bantuan sarana kebersihan, menyisihkan dana corporate sosial responsibilities (CSR), pengabdian masyarakat berupa penyuluhan kesehatan.

Mengacu pada teori fungsionalisme struktural bahwa upaya-upaya yang dilakukan dalam pengelolaan daya tarik wisata adalah merupakan fungsi nyata (manifest) dalam upaya meningkatkan kesejahteraan masyarakat. Teori fungsionalisme struktural memandang bahwa segala pranata sosial yang ada dalam masyarakat tertentu serba fungsional dalam artian positif dan negatif.

Prajuru dalam melaksanakan perannya merencanakan beberapa program kerja dan upaya-upaya yang harus dilakukan. Menurut teori hegemoni bahwa kelompok dominan menjalankan perannya menggunakan seperangkat ideologi ke dalam program atau upaya-upaya yang akan dilakukan secara sistematis untuk membangkitkan kesadaran anggotanya sedemikian rupa sehingga tanpa disadari warga masyarakat rela mendukung program yang direncanakan.

\section{Kesimpulan dan Saran}

Berdasarkan hasil pembahasan maka dapat ditarik beberapa kesimpulan. Pertama bentuk pengelolaan daya tarik wisata di Desa Pakraman Pecatu untuk Kawasan Luar Pura Uluwatu adalah pengelolaan yang langsung dilakukan oleh prajuru Desa Pakraman Pecatu bekerja sama dengan Pemerintah Desa Pecatu melalui pemberdayaan masyarakat warga Desa Pakraman Pecatu. Di daya tarik wisata yang lain belum terbentuk Badan Pengelola oleh Desa Pakraman Pecatu. Pengelolaan dilakukan oleh warga masyarakat yang berada di sekitarnya dengan memanfaatkan berbagai peluang di bidang jasa pariwisata.

Kedua, dalam pengelolaan daya tarik wisata oleh Desa Pakraman Pecatu menghadapi beberapa kendala berupa keterbatasan sumber daya manusia, keterbatasan fasilitas wisata, keterbatasan dana, sosial kemasyarakatan, belum adanya regulasi, kurangnya koordinasi antar lembaga dan unsur masyarakat dan kepemilikan lahan.

Ketiga, mengacu pada beberapa kendala yang dihadapi, Desa Pakraman Pecatu melakukan upaya-upaya seperti pembentukan manajemen daya tarik wisata, pembangunan dan penataan daya tarik wisata, menyiapkan regulasi 
pengelolaan daya tarik wisata, pemberdayaan masyarakat dan meningkatkan kerja sama antar lembaga. Upaya pengelolaan sudah mulai dilakukan dengan pembentukan manajemen pengelolaan daya tarik wisata Kawasan Luar Pura Uluwatu dan pembangunan serta penataan fasilitas wisata di Kawasan Luar Pura Uluwatu , Pantai Labuhan Sait dan Pantai Suluban.

Saran yang dapat direkomendasikan kepada pihak-pihak terkait adalah sebagai berikut. Pertama, kepada para peneliti dan mahasiswa, khususnya dalam bidang pariwisata, untuk melakukan penelitian lanjutan tentang potensi pariwisata lainnya yang tumbuh dan berkembang dalam kehidupan masyarakat di Desa Pakraman Pecatu seperti potensi budaya yang selama ini belum banyak diangkat sebagai daya tarik wisata.

Kedua, ditujukan kepada masyarakat khususnya di Desa Pakraman Pecatu yang merupakan pemilik sumber daya pariwisata agar dapat berperan serta dalam pengelolaan daya tarik wisata dengan selalu mengikuti, mendukung dan memberikan masukan terhadap program pengelolaan daya tarik wisata dari Desa Pakraman Pecatu, serta selalu meningkatkan kualitas sumber daya manusia.

Saran ketiga ditujukan kepada prajuru Desa Pakraman Pecatu dan Pemerintah Desa Pecatu agar dalam pengelolaan daya tarik wisata dilakukan secara profesional dengan menerapkan prinsip-prinsip manajemen. Sumber daya manusia yang berasal dari warga masyarakat Desa Pakraman Pecatu harus tetap diberdayakan dan diprioritaskan.

\section{Ucapan Terima Kasih}

Penulis menyampaikan ucapan terima kasih kepada Prof. Dr. I Nyoman Sirtha, SH. MS, sebagai pendahulu Ketua Program Studi Magister Kajian Pariwisata Universitas Udayana, dan kepada Prof. Dr. I Nyoman Darma Putra, M.Litt. selaku Ketua Program Studi Magister Kajian Pariwisata Universitas Udayana sekaligus sebagai pembimbing I dan Dr. Ir. I Made Adhika, MSP selaku pembimbing II yang dengan penuh perhatian dan kesabaran telah memberikan bimbingan dan saran kepada penulis. Ucapan terima kasih penulis sampaikan pula kepada para Prof. Dr. I Wayan Ardika, MA, Prof. Dr. I Made Sukarsa, MS dan Dr. I Nyoman Madiun, M.Sc yang telah memberikan masukan, saran, sanggahan dan koreksi dalam penulisan penelitian ini.

\section{Daftar Pustaka}

Barker, Ch. 2005. Cultural Studies, Teori dan Praktek. Yogyakarta: Yayasan Bentang Budaya.

Dharmayuda, S. I M. 2001. Desa Adat Kesatuan Masyarakat Hukum Adat di Propinsi Bali. Denpasar: Upada Sastra.

Dinas Pariwisata Kabupaten Badung. 2013. Profil Dinas Pariwisata Kabupaten Badung Tahun 2013. Mangupura: Pemda Badung. 
Haryatmoko,J. 1986. Manusia dan Sistem. Pandangan Tentang Manusia Dalam Sosiologi Talcott Parsons. Yogyakarta: Kanisius.

Inskeep, E.1991. Tourism Planning: An Integrated an Sustainable Approach. New York: Van Nostrand Reinhold Inc.

Pendit, S. I N. 1994. Ilmu Pariwisata Sebuah Pengantar Perdana. Jakarta: PT. Pradnya Paramita.

Pemerintah Desa Pecatu. 2012. Monografi Desa Pecatu. Mangupura: LPM Pecatu Pitana, I.G. 1996. Dinamika Masyarakat dan Kebudayaan Bali. Denpasar: Bali Post. Pitana, I.G. 1999. Pelangi Pariwisata Bali. Denpasar: Bali Post.

Pitana, I.G. 2002. Apresiasi Kritis Terhadap Kepariwisataan Bali. Denpasar: The Works.

Pitana, I.G dan Gayatri. 2005. Sosiologi Pariwisata. Yogyakarta: Andi.

Poloma, M. 2003. Sosiologi Kontemporer Cetakan kelima, diterjemahkan dari karya asli Contemporary sociological Theory oleh tim penerjemah Yasogama. Jakarta: Raja Grafindo Persada.

Rex, J. 1985. Analisa Sistem Sosial. Alih Bahasa Drs. Sahat Simamora. Jakarta: PT.Bina Aksara.

Ritzer, G. dan Douglas J. Goodman, 2003. Teori Sosial Modern Edisi Keenam diterjemahkan dari karya asli Modern Sociology Theory oleh Ahmadian (ed. Tribowo Budi Santoso). Jakarta: Prenada Media.

Spillane, J. 2002. Ekonomi Pariwisata, Sejarah dan Prospeknya. Yogyakarta: Kanisius.

Soekanto, S. 2009. Sosiologi Suatu Pengantar. Edisi Baru. Jakarta: PT. Raja Grafindo. Swarbrooke, J. 1999. Sustainable Tourism Management. London: CABI Publlishing. Yoeti, H. O. 1997. Perencanaan dan Pengembangan Pariwisata. Jakarta: PT. Pradnya Paramita.

Yoeti, H. O. 2002. Perencanaan Strategis Pemasaran Daerah Tujuan Wisata. Jakarta: PT. Pradnya Paramita.

\section{Peraturan Perundang-Undangan :}

Undang-Undang Republik Indonesia Nomor 10 Tahun 2009 Tentang Kepariwisataan. Peraturan Daerah Provinsi Bali Nomor 3 Tahun 1991 Tentang Pariwisata Budaya.

Peraturan Daerah Provinsi Bali Nomor 2 Tahun 2012 Tentang Kepariwisataan Budaya Bali.

Peraturan Daerah Kabupaten Badung Nomor 20 Tahun 1994 Tentang Pengusahaan dan Retribusi Objek Wisata.

Peraturan Daerah Kabupaten Badung Nomor 25 Tahun 2011 Tentang Retribusi Tempat Rekreasi dan Olah Raga.

Peraturan Bupati Badung Nomor 7 Tahun 2005 Tentang Objek dan Daya Tarik Wisata di Kabupaten Badung. 


\section{Profil Penulis}

I Ketut Yudasuara, SE, M.Par, menyelesaikan pendidikan Program Magister Kajian Pariwisata Universitas Udayana, Bali tahun 2015. Program sarjana ditempuh di Sekolah Tinggi Ilmu Manajemen Indonesia (STIMI) Handayani Denpasar pada Program Studi Manajemen Konsentrasi Bisnis Pariwisata, diselesaikan tahun 2002. Ia pernah mengikuti pendidikan Diploma III Manajemen Perhotelan STP Negeri Bali (dulu BPLP Nusa Dua) tahun 1991 dan program Akta IV IKIP PGRI Bali tahun 2010. Kini ia bekerja sebagai guru mata pelajaran perhotelan dan kepariwisataan di SMK Pariwisata Harapan Denpasar. Ia juga pernah menjadi dosen di beberapa perguruan tinggi antara lain PPLP Dhyana Pura, Mapindo, AKPAR Triatma Jaya dan Politeknik Nasional Denpasar. Ia aktif sebagai pengurus Majelis Guru Mata Pelajaran Akomodasi Perhotelan Kota Denpasar, pengurus Koperasi Angga Koripan Denpasar dan Sekretaris Badan Permusyawaratan Desa Pecatu. 